\title{
Evaluasi Kinerja Pegawai Bagian Program Kemitraan dan Bina Lingkungan pada PT. Perkebunan Nusantara III (Persero) Medan
}

\author{
Abdul Kadir* \& Raja Alamsyah Hasbullah Pane \\ Program Studi Ilmu Administrasi Publik, Fakultas Ilmu Sosial dan Ilmu Politik \\ Universitas Medan Area, Indonesia \\ Diterima: November 2018; Disetujui: November 2018; Dipublish: Desember 2018
}

\begin{abstract}
Abstrak
Penelitian ini bertujuan untuk mengetahui Evaluasi Kinerja Pegawai Bagian Program Kemitraan dan Bina Lingkungan di PT.Perkebunan Nusantara III (Persero) Medan. Kinerja pegawai merupakan hasil kerja yang dapat dicapai seseorang atau sekelompok orang dalam suatu organisasi sesuai wewenang dan tanggung jawab masing-masing dalam rangka mewujudkan tujuan organisasi, dimana disini akan mengevaluasi kinerja pegawai bagian Program Kemitraan dan Bina Lingkungan pada PT.Perkebunan nusantara III (Persero) Medan di tahun 2016 yang lalu. Dimana banyak indikator yang dapat mengukur kinerja seorang pegawai. Dengan melihat beberapa indikator untuk menentukan keberhasilan kinerja yaitu produktivitas, kualitas layanan, responsivitas, responsibilitas dan akuntabilitas,di Penelitian ini menggunakan metode deksriptif kualitatif, lokasi penelitian dilakukan di kantor Bagian Program Kemitraan dan Bina Lingkungan di PT.Perkebunan Nusantara III (Persero) Medan, teknik pengumpulan data adalah wawancara, observasi dan dokumentasi, dapat disimpulkan bahwa Evaluasi Kinerja Pegawai Bagian Program Kemitraan dan Bina Lingkungan di PT.Perkebunan Nusantara III (Persero) Medan sangat baik.
\end{abstract}

Kata Kunci: Evaluasi, Kinerja Pegawai, Program Kemitraan, Bina Lingkungan

\begin{abstract}
This study aims to determine the Employee Performance Evaluation of the Partnership and Community Development Program Section at PT. Perkebunan Nusantara III (Persero) Medan. Employee performance is the work that can be achieved by a person or group of people in an organization according to the authority and responsibility of each in order to realize the goals of the organization, which here will evaluate the performance of employees in the Partnership and Community Development Program at PT. Nusantara Nusantara III (Persero) Medan in 2016. Where many indicators can measure the performance of an employee. By looking at several indicators to determine performance success, namely productivity, service quality, responsiveness, responsibility and accountability, in this study using qualitative descriptive methods, the location of the study was conducted at the Office of the Partnership and Community Development Program at PT. Perkebunan Nusantara III (Persero) Medan, Data collection techniques are interviews, observation and documentation, it can be concluded that the Employee Performance Evaluation Section of the Partnership and Community Development Program at PT. Perkebunan Nusantara III (Persero) Medan is very good.
\end{abstract}

Keywords: Evaluation, Performance Employee, Partnership Program, Community Development

How to Cite: Kadir, A. \& Pane, R.A.H. (2018). Evaluasi Kinerja Pegawai Bagian Program Kemitraan Dan Bina Lingkungan Pada PT. Perkebunan Nusantara III (Persero) Medan. JUPIIS: Jurnal Pendidikan Ilmuilmu Sosial, Vol. 10 (2): 205-209

${ }^{*}$ Corresponding author: ISSN 2085-482X (Print)

E-mail: abdulkadir@staff.uma.ac.id. ISSN 2407-7429 (Online) 


\section{PENDAHULUAN}

Kinerja pegawai merupakan hasil kerja yang dapat dicapai seseorang atau sekelompok orang dalam suatu organisasi sesuai wewenang dan tanggung jawab masing-masing dalam rangka mewujudkan tujuan organisasi, pemimpin harus dapat memobilisasi sebuah tim, proses pekerjaan harus dapat dikembangkan dan proses sumber daya manusia harus menjadi fokus utama, perubahan dan peningkatan peran fungsi sumber daya manusia sangat esensial untuk mendukung keberhasilan organisasi,dimana disini akan mengevaluasi kinerja pegawai bagian Program Kemitraan dan Bina Lingkungan pada PT.Perkebunan nusantara III (Persero) Medan di tahun 2016 yang lalu.

Pengelolaan sumber daya manusia terkait dan mempengaruhi kinerja organisasional dengan cara menciptakan nilai atau menggunakan keahlian sumber daya manusia yang berkaitan dengan praktek manajemen dan sasarannya cukup luas, tidak hanya terbatas karyawan operasional semata, namun juga meliputi tingkatan manajerial.

Sumber daya manusia sebagai penggerak organisasi banyak dipengaruhi oleh perilaku para pesertanya (partisipannya) atau aktornya. Keikutsertaan sumber daya manusia dalam organisasi diatur dengan adanya pemberian wewenang dan tanggung jawab. Merumuskan wewenang dan tanggung jawab yang harus dicapai pegawai dengan standar atau tolak ukur yang telah ditetapkan dan disepakati oleh pegawai dan atasan. Pegawai bersama atasan masing-masing dapat menetapkan sasaran kerja dan standar kinerja yang harus dicapai serta menilai hasil-hasil yang sebenarnya dicapai pada akhir kurun waktu tertentu.

Evaluasi kinerja adalah suatu metode dan proses penilaian dan pelaksanaan tugas seseorang atau sekelompok orang atau unit-unit kerja dalam satu perusahaan atau organisasi sesuai dengan standar kinerja atau tujuan yang ditetapkan lebih dahulu. Evaluasi kinerja merupakan cara yang paling adil dalam memberikan imbalan atau penghargaan kepada pekerja.

Tujuan evaluasi kinerja adalah untuk menjamin pencapaian sasaran dan tujuan perusahaan dan juga untuk mengetahui posisi perusahaan dan tingkat pencapaian sasaran perusahaan, terutama untuk mengetahui bila terjadi keterlambatan atau penyimpangan supaya segera diperbaiki, sehingga sasaran atau tujuan tercapai.

Evaluasi kinerja pada dasarnya dilakukan untuk mengetahui sejauh mana kadar profesionalisme serta seberapa tepat pegawai telah menjalankan fungsinya. Penilaian kinerja dimaksudkan untuk menilai dan mencari jenis perlakuan yang tepat sehingga pegawai dapat berkembang lebih cepat sesuai dengan harapan. Ketepatan pegawai dalam menjalankan fungsinya akan sangat berpengaruh terhadap pencapaian kinerja organisasi secara keseluruhan.Tidak sedikit di perusahaan-perusahaan swasta maupun negeri yang melakukan evaluasi kinerja pegawai tidak tepat, tidak sesuai dengan situasi dan kondisi yang ada.

$$
\text { Tujuan pelaksanaan Program }
$$

Kemitraan Program Bina Lingkungan dapat tercapai, dibentuk bagian tersendiriyang khusus melaksanakan Program Kemitraan dan Program Bina Lingkungan selanjutnya disebut Bagian Kemitraan dimana bagian ini memiliki tugas dan fungsi sebagai bagian yang memberikan pinjaman terhadap masyarakat yang mana dengan jaminan yang telah disepakati dan dibayar dengan waktu yang disepakati juga,sedangkan bagian bina lingkungan dimana memiliki tugas dan fungsi sebagai pemberi dana hibah bagi masyarakat dengan syarat yang telah ditentukan oleh direksi PT.Perkebunan Nusantara III (Persero),Medan.

Maka dari itu peneliti merasa tertarik untuk melakukan penelitian terhadap 
Evaluasi Kinerja pegawai bagian Program Kemitraan dan Bina Lingkungan(PKBL) di PT.Perkebunan

Nusantara

III

(Persero),Medan.

Berdarasarkan latar belakang masalah yang diuraikan diatas, maka permasalahan dalam penelitian ini adalah untuk mengetahui bagaimana Kinerja Pegawai Bagian Program Kemitraan dan Bina Lingkungan(PKBL) di PT.Perkebunan Nusantara III (Persero), Medan.

\section{METODE PENELITIAN}

Metode penelitian ini menggunakan metode Penelitian Kualitatif. Menurut Sugiyono (2014) metode penelitian kualitatif adalah metode yang digunakan untuk meneliti obyek yang alamiah dimana peneliti sebagai instrument kunci, tehnik pengumpulan data secara triangulasi, analisis databersifat induktif dan hasil penelitian kualitatif lebih menekankan makna.

Dalam metode penelitian kualitatif penulis ikut berpartisipasi langsung ke lapangan. Peneliti melihat, mengamati dan mengumpulkan data melalui wawancara mendalam, observarsi serta dokumentasi berdasarkan fakta dilapangan, melalui hasil tersebut peneliti dapat menuliskan laporan secara detail sehingga menghasilkan pemahaman secara spesifik.

Sutrisno Hadi dalam Sugiyono (2013) observasi merupakan suatu proses yang kompleks, suatu proses yang tersusun dari berbagai proses biologis dan psikologis. Dua di atara yang terpenting adalah proses-proses pengamatan dan ingatan.

Menurut Esterberg dalam Sugiyono (2013) Wawancara merupakan pertemuan dua orang untuk bertukar informasi dan ide melalui Tanya jawab, sehinhgga dapat dikontruksikan makna dalam suatu topik tertentu. Menurut Sugiyono (2013) dokumen merupakan catatan peristiwa yang sudah berlalu. Dokumen bisa berbentuk tulisan, gambar, atau karyakarya monumental dari seorang. Studi dokumen merupakan pelengkap dari penggunaan metode observasi dan wawancara dalam penelitian kualitatif.

Dalam teknik pengumpulan data, menggunakan triangulasi diartikan sebagai teknik pengumpulan data yang bersifat menggabungkan data dan sumber data yang telah ada. Analisis data dalam penelitian kualitatif, dilakukan pada saat pengumpulan data berlangsung, dan setelah selesai pengumpulan data dalam periode tertentu. Miles dan Huberman (1984), mengemukakan aktivitas dalam analisis data kualitatif dilakukan secara interaktif dan berlangsung secara terus menerus sampai tuntas, sehingga datanya jenuh. Aktivitas dalam analisis data meliputi : data reduction (reduksi data), data display (penyajian data), dan conclusion drawing (verification dan penarikan kesimpulan).(Sugiyono, 2007). Menurut Moleong (2005) memaparkan tujuan uji (credibility) kredibilitas data yaitu untuk menilai kebenaran dari temuan penelitian kualitatif. Kredibilitas ditunjukkan ketika partisipan mengungkapkan bahwa transkrip penelitian memang benar-benar sebagai pengalaman dirinya sendiri. Dalam hal ini peneliti akan memberikan data yang telah ditranskripkan untuk dibaca ulang oleh partisipan. Kredibilitas menunjukkan kepercayaan terhadap data hasil penelitian kualitatif. Selanjutnya menurut Lexy J. Moleong (2009) untuk menetapkan keabsahan data (trustworthiness) data diperlukan teknik pemeriksaan.

Pelaksanaan teknik pemeriksaan didasarkan atas sejumlah criteria tertentu. Ada empat criteria yang digunakan, yaitu derajat kepercayaan (credibility), keteralihan (transferability), kebergantungan (dependability), dan kepastian (confirmability). Untuk menjaga keabsahan data, maka yang dipergunakan adalah teknik pengamatan lapangan dan teknik triangulasi data. 


\section{HASIL DAN PEMBAHASAN}

Dimana Program Kemitraan merupakan suatu program yang bertujuan secara spesifik untuk membantu meningkatkan perekonomian masyarakat sekitar perusaahan tersebut didirikan,dengan membuat perjanjian dimana calon mitra yang ingin melakukan kerjasama harus menjamin sebuah agunan yang akan menjadi penjamin ketika mitra melakukan peminjaman terhadap bagian Program kemitraan dan Bina Lingkungan ini,biasanya ini meminjam modal usaha.

Sedangkan Bina Lingkungan merupakan suatu program yang mana bagian Program Kemitraan dan Bina Lingkungan ini membantu dengan cara menghibahkan laba yang telah diperoleh dari program kemitraan tersebut,Bina Lingkungan ini mencari target yaitu sekolahan,rumah agama,jalan pedesaan maupun bantuan untuk acara acara yang berguna.

Berdasarkan hasil wawancara kepda informan Kunci ,Utama dan Tambahan Bahwa Evaluasi Kenerja pegawai yang dilakukan telah dilakukan sesusai dengan standart operasional prosedur yang mana Penulis melakukan penelitian menggunkan teori dari Dwiyanto (2006) menjelaskan beberapa indikator yang digunakan untuk mengukur kinerja birokrasi public: Produktivitas, kualitas layanan, Responsivitas, Responsibilitas dan Akuntabilitas

Produktivitas, adalah pernyataan yang diberikan oleh Informan Kunci,Utama dan Tambahan dapat disimpulkan bahwa pungukuran Produktifitas yang dikemukakan Dwiyanto tidak menjamin baik tidaknya tingkat produktivitas, bahkan di Bagian Program Kemitraan dan Bina Lingkungan ini hanya satu yang menjadi pengukur produktivitas yaitu kompetensi diri,dimana setiap pegawai sudah teruji dan memiliki kompetensi yang baik sehingga kecil kemungkinan produktivitas di bagian Program
Kemitraan dan Bina Lingkungan tidak tercapai.

Kualitas layanan, dilihat dari hasil yang sudah dijelaskan oleh Informan Kunci, Utama dan Tambahan yang bekerjasama dengan bagian ini dapat disimpul bahwa kualitas layanan yang diberikan pegawai Bagian Program Kemitraan dan Bina Lingkungan sangat baik dan masyarakat yang menerimanya juga merasa puas akan layanan yang diberikan oleh pegawai bagian Program Kemitraan dan Bina Lingkungan sehingga semakin banyak yang ingin bekerjasama untuk memajukan ekonomi mereka dan itu sesuai dengan tujuan dari Bagian Program Kemitaan dan Bina lingkungan itu sendiri.

Responsivitas, dilihat dari hasil wawancara atas Informan Kunci,Utama dan Tambahan dapat disimpulkan kembali bahwa responsivitas yang diberikan oleh pegawai bagian Program Kemitraan dan Bina Lingkungan sudah sangat baik mulai dari Survey lapangan, Pengumpulan Uang iuaran yang langsung dijemput dilokasi serta tim penerima keluh kesah yang di berikan oleh mitra terhadap kinerja pegawai dibagian program kemitraan Bina Lingkungan ini,akan tetapi sayangnya responsivitas yang diberikan tidak di balas dengan baik oleh beberapa mitra yang jahat,mulai dari nunggak iuran, lari dari tanggung jawab serta sama sekali hilang dari lokasi yang telah dijadikan alamatnya,dan itu membuat kinerja pegawai sebenarnya terhambat, bukan hanya responsivitas saja bahkan berpengaruh terhadap produktivitas bagi pegawai yang melakukan tugasnya tersebut.

Responsibilitas hampir sama dengan responsivitas dimana responsibilitas ini lebih mengacu kepada prinsip-prinsip Adminitrasi yang mana suatu prosen kegiatan admnistrasi yang dilakukan pegawai dibagian Program kemitraan dan Bina Lingkungan apakah sudah sesuai dengan Prinsip-prinsip administras dan kebijakan dari birokrasi itu sendiri,dan 
yang terjadi di bagian Program Kemitraan dan Bina Lingkungan semuanya mengikuti prosedur yang telah ditetapkan oleh direksi yang mana direksi merupakan kepala dari seluruh Bagian yang berada diruang lingkup PT.Perkebunan Nusantara III(Persero),Medan.

Akuntabilitas, dilihat dari pernyataan informan Kunci, Utama dan Tambahan dapat disimpulkan bahwa akuntabilitas antara pegawai bagian Program Kemitraan dan Bina Lingkungan den gan mitra yang bekerjasama sudah transparansi dan berjalan dengan baik.

\section{SIMPULAN}

Berdasarkan hasil penelitian dan analisa data sebelumnya,secara umum Kinerja Pegawai Bagian Program Kemitraan dan Bina Lingkungan di PT.Perkebunan Nusantara III (Persero)Medan sudah sangat baik dan lancar dilihat dari hasil evaluasi yang menggunakan Teori dari Agus Dwiyanto (2006) dalam bukunya Mewujudkan Good Governance melalui Pelayanan Publik mengenai pengukuran kinerja pegawai. Dimana dengan menggunakan teori dari Dwiyanto untuk mengevaluasi kinerja pegawai bagian Program Kemitraan dan Bina Lingkungan di PT.Perkebunan Nusantara III (Persero), Medan. Didalam teori yang dikemukakan Dwiyanto terdapat lima (5) indikator untuk mengukur kinerja pegawai,diantaranya: Produktivitas, Kualitas layanan, Responsivitas, Responsibilitas, dan Akuntabilitas. Dimana kelima indikator tersebut semuanya berjalan dengan baik dan sesuai dengan yang disepakati bersama,dengan kata lain kinerja pegawai bagian Program Kemitraan dan Bina Lingkungan sudah sangat baik

\section{DAFTAR PUSTAKA}

Aminudin, M. (2007). Evaluasi Rencana Lokasi Pemindahan Terminal Induk Km. 6 Banjarmasin. (Tesis). Yogyakarta: MPKD Universitas Gadjah Mada.
Aprilia, H. (2009). Evaluasi Pelaksanaan Program Transmigrasi Lokal Model Ring I Pola Tani Nelayan di Bugel, Kec. Panjatan, Kab. Kulon Progo dan Gesing, Kec. Panggang Kab. Gunung Kidul. (Tesis). Yogyakarta: MPKD Universitas Gadjah Mada.

Bryan, C dan Louis G. W., (1987). Manajemen Pembangunan Untuk Negara Berkembang. LP3ES. Jakarta.

Dharma, S. (2004). Manajemen Kinerja, Falsafah, Teori dan Penerapannya. Pustaka Pelajar: Yogyakarta.

Dwiyanto, A. (2006) Mewujudkan Good Governance melalui Pelayanan Publik. Indikator Kinerja Pegawai.. PT. Rajagrafindo Persada: Jakarta

Ilyas, Y. (2005). Kinerja, Teori dan Penelitian. Liberty: Yogyakarta.

Keputusan Menteri Keuangan No.:316/KMK.016/1994 tanggal 27 Juni 1994 tentang Pedoman Pembinaan Usaha Kecil dan Koperasi melalui Pemanfaatan Dana dari Bagian Laba Badan Usaha Milik Negara

Lumentah, J.G. (2015) Evaluasi Kinerja Pegawai Negeri Sipil Dalam Meningkatkan Pelayanan Publik Di Kantor Camat Tompaso Kabupaten Minahasa pada tahun 2015

Mangkunegara, A.P. (2005). Manajemen Sumber Daya Manusia Perusahaan, Cetakan keenam. Remaja Rosda Karya: Bandung.

Menteri BUMN Nomor 236/MBU/2003,yaitu untuk memberdayakan masyarakat, meningkatkan kesejahteraan sosial dan pertumbuhan ekonomi masyarakat secara berkesinambungan, dengan tetap menjaga kelestarian lingkungan

Miles, B. M dan Huberman, M. (1992). Analisis Data Kualitatif (Buku Sumber tentang Metodemetode Baru). Jakarta: UIP.

Moleong, L.J. (2008). Metodologi Penelitian Kualitatif. Bandung: PT. Remaja Rosdakarya.

Peraturan Pemerintah No 39 Tahun 2006 tentang Tata Cara Pengendalian dan Evaluasi Pelaksanaan Rencana Pembangunan

Rivai, V. (2005). Manajemen Sumber Daya Manusia Untuk Perusahaan, Dari Teori Ke Praktek. PT. Rajagrafindo Persada: Jakarta.

Saparuddin. (2007). Teori supervisi kepemimpinan pada buku yang diterbitkan

Scriven, M. (1991). Evaluation thesaurus (4th ed.). Newbury Park, CA: Sage.

Sendow. (2007). Pengukuran Kinerja Karyawan. Gunung Agung: Jakarta.

Simamora, H. (2004). Manajemen Sumber Daya Manusia. STIE.YKPN: Jogjakarta.

Sugiyono. (2011). Metode Penelitian Administratif. Bandung: Alfabeta. 
Abdul Kadir \& Raja Alamsyah Hasbullah Pane, Evaluasi Kinerja Pegawai Bagian Program Kemitraan

Sugiyono. (2013). Metode Penelitian Pendidikan Pendekatan Kuantitatif, Kualitatif, dan R\&D. Bandung: Alfabeta.
Sumarni, M. (2014). Metodologi Penelitian Bisnis. Yogyakarta: PT. Liberty

Sutrisno, H. (2009). Manajemen Sumber Daya Manusia. Andi Offset: Yogyakarta 